\title{
Interleukin-8 induction and adhesion of the coccoid form of Helicobacter pylori
}

\author{
TAKAKO OSAKI, HIROYUKI YAMAGUCHI, HARUHIKO TAGUCHI, MINORU FUKADA*, \\ HAYATO KAWAKAMI†, HIROSHI HIRANO† and SHIGERU KAMIYA \\ Division of Medical Microbiology, Department of Infectious Diseases, $*$ Laboratory for Electron Microscopy and \\ $\dagger 2 n d$ Department of Anatomy, Kyorin University School of Medicine, Shinkawa, Mitaka, Tokyo, Japan
}

\begin{abstract}
To determine the pathological significance of the coccoid form of Helicobacter pylori, its adhesion to and induction of secretion of interleukin-8 (IL-8) by gastric epithelial (MKN45) cells were studied. By flow cytometry, the adhesion of the coccoid form to MKN45 cells was significantly lower than that of the helical form. The monoclonal antibody A20 recognising lipopolysaccharide of $\mathrm{H}$. pylori inhibited the adhesion of the coccoid form to MKN45 cells as much as that of the helical form. There was significantly lower induction of IL-8 secretion by MKN45 cells exposed to the coccoid form (two of four strains) as compared with the helical form.
\end{abstract}

\section{Introduction}

Helicobacter pylori changes its morphology in vitro from a helical form to a coccoid form under various conditions such as extended cultivation $[1,2]$, aerobic culture [3], alkaline $\mathrm{pH}$ [3] and antibiotic treatment $[4,5]$. In the human stomach, the ability of the helical form of the micro-organism to colonise gastric mucosa and to attach to mucosal epithelial cells has been well documented. The coccoid form of the micro-organism has also been observed in human stomach by immunohistochemistry method [6] and by electron microscopy [7]. It has been reported that the coccoid form of $H$. pylori is non-culturable but viable and metabolically active $[2,5,8]$. The role of the coccoid form in the transmission and pathogenesis of $H$. pylori infection is still unclear. Therefore, this study compared these two forms with respect to their ability to adhere to MKN45 cells.

Furthermore, since the helical form of $H$. pylori adheres to gastric epithelial cells and induces interleukin8 (IL-8) secretion [9], the induction of IL-8 secretion from MKN45 cells by both forms of $H$. pylori was also studied.

Received 17 April 2001; revised version accepted 22 Sept. 2001.

Corresponding author: Dr T. Osaki (e-mail: osaki@ kyorin-u.ac.jp.

\section{Materials and methods}

Bacterial strains and culture conditions

H. pylori strains, TK1029, TK1045, TK1401 and TK1407 isolated from gastric biopsies were used to measure adhesion to epithelial cells. These strains were cultured on Brain Heart Infusion (BHI) Agar (Difco Laboratories, Detroit, MI, USA) supplemented with horse blood 7\% in an atmosphere consisting of $\mathrm{O}_{2} 5 \%$, $\mathrm{CO}_{2} 10 \%, \mathrm{~N}_{2} 85 \%$ for 2 days at $37^{\circ} \mathrm{C}$. To prepare the coccoid form, $H$. pylori was incubated micro-aerobically on BHI blood agar at $37^{\circ} \mathrm{C}$ for 3 days and subsequently incubated in an anaerobic atmosphere consisting of $\mathrm{H}_{2} 5 \%, \mathrm{CO}_{2} \quad 10 \%, \mathrm{~N}_{2} 85 \%$ in an anaerobic box (Hirasawa, Tokyo, Japan) at $30^{\circ} \mathrm{C}$ for $7-10$ days.

\section{Cell line}

Human gastric carcinoma cells, MKN45, were obtained from the Japanese Cancer Research Resources Bank. For the adhesion assay, MKN45 cells were grown in air with $\mathrm{CO}_{2} 5 \%$ at $37^{\circ} \mathrm{C}$ in RPMI-1640 (Gibco BRL, Gaithersburg, MD, USA) containing fetal calf serum (FCS) $10 \%$ and harvested from a flask by scraping with a sterile cell scraper.

\section{Adhesion assay}

The adhesion of $H$. pylori was assessed by flow cytometry [10]. H. pylori $\left(5 \times 10^{8}\right.$ cells $)$ were labelled at room temperature for $15 \mathrm{~min}$ with $4 \mu \mathrm{M}$ lipophilic dye, PKH-2 (Zynaxis Cell Sciences, Phoenixville, PA, 
USA), and washed twice with Hanks's Balanced Salts Solution containing gelatin $0.1 \%$ (HGS). MKN45 cells (c. $1 \times 10^{6}$ cells) were washed once with HGS and resuspended in $500 \mu \mathrm{l}$ of HGS. H. pylori were also resuspended in $500 \mu \mathrm{l}$ of HGS and co-incubated with the cells for $1 \mathrm{~h}$ at room temperature. After incubation, the cells were washed once with PBS containing sucrose $15 \%$ and subsequently washed twice with HGS. The fluorescence intensity of the cells was analysed with a flow cytometer (FACS Vantage, Beckton Dickinson, San Jose, CA, USA). Mean fluorescence intensity (MFI) was calculated by Cell Quest (Beckton Dickinson). The adhesion index was calculated from the MFI as follows: adhesion index $=($ MFI of MKN45 cell with adherent $H$. pylori - MFI of MKN45 cells)/(MFI of PKH-2 labelled H. pylori-MFI of non-labelled $H$. pylori). The inhibition of adhesion of $H$. pylori to epithelial cells by monoclonal antibody (MAb) A20 was tested as described previously [11].

The adhesion of $H$. pylori was examined by electron microscopy. MKN45 cells $\left(1 \times 10^{5}\right)$ were seeded on to poly-L-lysine-coated cover glasses (Iwaki, Tokyo, Japan) in a 24-well culture plate (Iwaki). Cells were centrifuged at $1000 \mathrm{~g}$ and washed with HGS. Then $100 \mu \mathrm{l}$ of suspension of $H$. pylori $\left(10^{8}\right.$ cells $\left./ \mathrm{ml}\right)$ in RPMI-1640 were placed on each cover glass and incubated for $30 \mathrm{~min}$ at room temperature. The cover glasses were removed and washed twice with HGS. The cells were fixed first with glutaraldehyde 2.5\% solution and then with osmic acid 2\% solution. Adhesion of $H$. pylori was observed with a JSM5600LV scanning electron microscope (Jeol, Tokyo, Japan). The number of adherent bacteria on 25 gastric cells was counted. Welch's $t$ test was used for statistical comparisons.

\section{IL-8 induction assay}

For IL-8 induction, MKN45 cells were seeded at $5 \times 10^{5}$ cells/well in six-well culture plates just before infection. H. pylori were added to the cell culture at $5 \times 10^{7}$ cells/well. The supernates were collected 24 and $48 \mathrm{~h}$ after the infection, and IL-8 concentrations were determined by enzyme-linked immunosorbent assay (Quantikine; R\&D Systems, Minneapolis, MN, USA).

\section{ELISA}

Cultures of $H$. pylori were harvested and then washed with phosphate-buffered saline (PBS). Cells were resuspended in PBS and treated with a Sonifer 250 (Branson Ultrasonic, Danbury, USA) for $1 \mathrm{~min}$ at 20 $\mathrm{kHz}$ twice. Microtitration plates (Greiner Labortechnik Japan, Tokyo, Japan) were coated with the sonicated antigen $(2000 \mathrm{pg} / \mathrm{ml})$ of $H$. pylori. After treatment with MAb A20 $1 \mu \mathrm{g} / \mathrm{ml}$ - which recognises lipopolysaccharide (LPS) of H. pylori [10] - for $1 \mathrm{~h}$ at room temperature, the bound $\mathrm{MAb}$ was detected with an affinity-purified goat anti-mouse IgG and IgM horseradish peroxide conjugate (Biosource International, Camarillo, CA, USA) diluted 1 in 5000 with PBS containing skimmed milk $1 \%$. Then, the plates were developed with OPD buffer $(0.1 \mathrm{M}$ citric acid, $0.07 \mathrm{M}$ sodium phosphate dibasic, and $\mathrm{H}_{2} \mathrm{O}_{2} \quad 0.015 \%$ ) containing $o$-phenylenediamine $0.1 \%$.

\section{Results}

\section{Preparation of the coccoid form of $H$. pylori}

By microscopic analysis, $>99 \%$ of $H$. pylori strain TK1029 were of the helical form after micro-aerobic cultures for 2 days. However, after subsequent culture under anaerobic condition for 7 days, $>95 \%$ of the bacteria had changed to the coccoid form. Similarly, another three strains of $H$. pylori were changed to the coccoid form after anaerobic culture for 7-10-days. These coccoid bacteria could not grow on BHI agar containing blood $7 \%$ under micro-aerobic conditions.

\section{Adhesion assay to MKN45 cells}

Adhesion to MKN45 cells was examined by flow cytometry for both the coccoid and helical forms (Table 1). The adhesion of the coccoid form was significantly lower than that of the helical form for two H. pylori strains (TK1029 and TK1045, p <0.05)

Scanning electron microscopy was used to illustrate the adhesion of the helical form of $H$. pylori strain TK1029 to MKN45 cells (Fig. 1a). Similarly, it was shown that the coccoid form of the same strain adhered to MKN45 cells (Fig. 1b). The mean numbers of coccoid and helical forms adhering to MKN45 cells were 11.4 SD 10.3 and 40.0 SD 17.8, respectively. The number of coccoid forms adhering to cells was significantly lower than that of the helical form $(p<0.01)$.

\section{Adhesion inhibition by MAb A20}

The reactivity of MAb A20 with the helical and coccoid forms of 12 strains of $H$. pylori was tested by ELISA. The mean of ELISA values of the coccoid and helical forms were 0.319 SD 0.224 and 0.417 SD 0.318 , respectively (data not shown). MAb A20 reacted with the coccoid form as well as with the helical form,

Table 1. Comparison of adhesion of helical and coccoid forms of Helicobacter pylori to MKN45 cells

\begin{tabular}{lcc}
\hline & \multicolumn{2}{c}{ Mean (SD) adhesion index } \\
\cline { 2 - 3 } Strain & Helical form $^{*}$ & Coccoid form $^{\dagger}$ \\
\hline TK1029 & $32.3(21.5)$ & $6.7(0.9)^{\dagger}$ \\
TK1401 & $13.0(11.2)$ & $7.2(3.8)$ \\
TK1407 & $12.8(1.0)$ & $9.7(6.4)^{\dagger}$ \\
TK1045 & $40.2(23.8)$ & $4.0(0.8)$ \\
\hline
\end{tabular}

\footnotetext{
${ }^{*}$ Data were obtained from four independent experiments.

${ }^{\dagger}$ Data were obtained from three independent experiments.

${ }_{\mathrm{p}}<0.05$ compared with the helical form by Welch's $t$ test.
} 

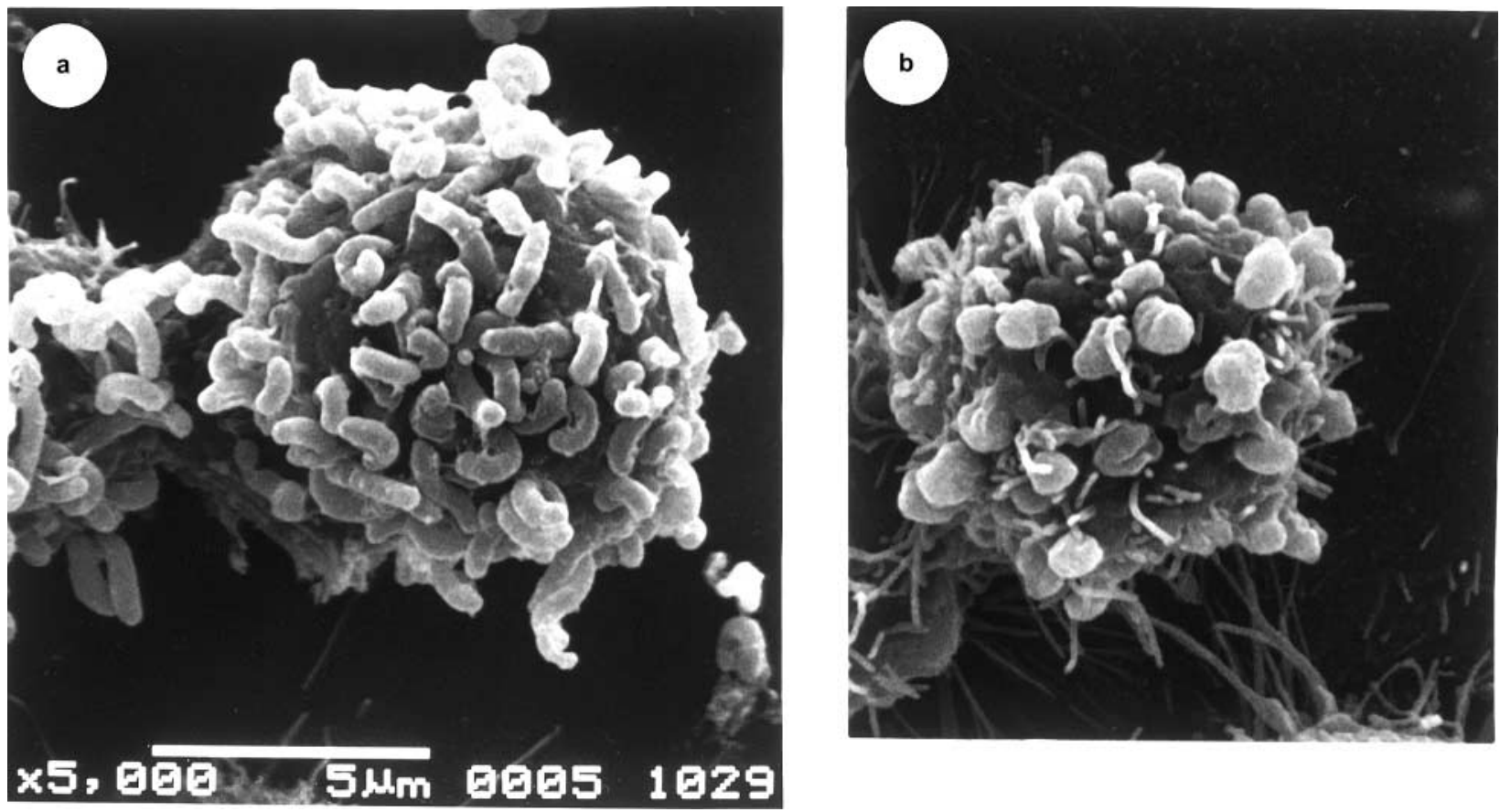

Fig. 1. Adhesion of H. pylori helical form (a) and coccoid form (b) to MKN45 cells $(\times 6000)$.

although the MFI of MKN45 cells with the helical form (24.6 SD 13.9) was significantly higher than that of MKN45 cells with the coccoid form (6.9 SD 2.3, $\mathrm{p}<0.05)$.

With MAb A20, adhesion of helical and coccoid forms of $H$. pylori strain TK1029 to MKN45 cells was compared (Table 2). MAb A20 markedly inhibited adhesion of both the helical and coccoid forms, and there was no significant difference in the inhibition rate between the helical and coccoid forms.

\section{Induction of IL-8 secretion}

IL-8 secretion by MKN45 cells following interaction with the helical and coccoid forms of four $H$. pylori strains was tested. It was shown (Fig. 2) that significantly greater IL-8 secretion was observed in MKN45 cells interacting with the helical form of two strains (TK1401 and TK1029) compared with the corresponding coccoid forms. On the other hand, when the other two strains (TK1045 and TK1407) were tested, there was no significant difference in the induction of IL-8 secretion in MKN45 cells.

\section{Discussion}

It has been reported that $H$. pylori changes its morphology from helical to coccoid form under various conditions such as long-term incubation, antibiotic treatment, acidic conditions, etc. [1,2]. This study showed that the helical form of the bacteria changed to the coccoid form within 7-10 days when cultured under anaerobic conditions. This study has shown that the adhesion of the coccoid form to MKN45 cells was lower than that of the helical form as assessed by flow cytometry. Furthermore, adhesion of helical and coccoid forms of $H$. pylori strain TK1029 was significantly inhibited by MAb 20 that recognised its LPS, although there was no difference in the reactivity with $\mathrm{MAb} \mathrm{A} 20$ in an ELISA between the helical and coccoid forms. This result suggests that LPS containing the epitope reacting with MAb A20 in the ELISA may

Table 2. Inhibition of adhesion of H. pylori TK1029 to MKN45 cells by MAb A20*

\begin{tabular}{lccccccc}
\hline & \multicolumn{3}{c}{ Helical form } & & \multicolumn{3}{c}{ Coccoid form } \\
\cline { 2 - 5 } \cline { 7 - 8 } $\begin{array}{l}\text { Number of } \\
\text { H. pylori } \\
(\mathrm{cfu})\end{array}$ & $\begin{array}{c}\text { Untreated } \\
\left(\mathrm{MFI}^{\dagger}\right)\end{array}$ & $\begin{array}{c}\text { Treated } \\
(\mathrm{MFI})\end{array}$ & $\begin{array}{c}\text { Inhibition } \\
(\%)\end{array}$ & & $\begin{array}{c}\text { Untreated } \\
\left(\mathrm{MFI}^{\dagger}\right)\end{array}$ & $\begin{array}{c}\text { Treated } \\
(\mathrm{MFI})\end{array}$ & $\begin{array}{c}\text { Inhibition } \\
(\%)\end{array}$ \\
\hline $10^{8}$ & 2098.5 & 1613.8 & 23.1 & & 1108.3 & 732.7 & 33.8 \\
$10^{7}$ & 463.1 & 226.1 & 51.2 & & 162.0 & 68.2 & 57.9 \\
$10^{6}$ & 46.9 & 26.4 & 43.7 & & 18.1 & 10.1 & 44.3 \\
\hline
\end{tabular}

${ }^{*} H$. pylori were incubated with MAb A20 $(400 \mu \mathrm{g} / \mathrm{ml})$ at $37^{\circ} \mathrm{C}$ for $1 \mathrm{~h}$.

${ }^{\dagger}$ Adhesion of $H$. pylori to MKN45 cells was expressed as mean fluorescence intensity (MFI).

${ }^{*}$ Inhibition $=($ MFI of non-treated cells - MFI of pretreated cells by MAb A20)/MFI of nontreated cells $\times 100$. 

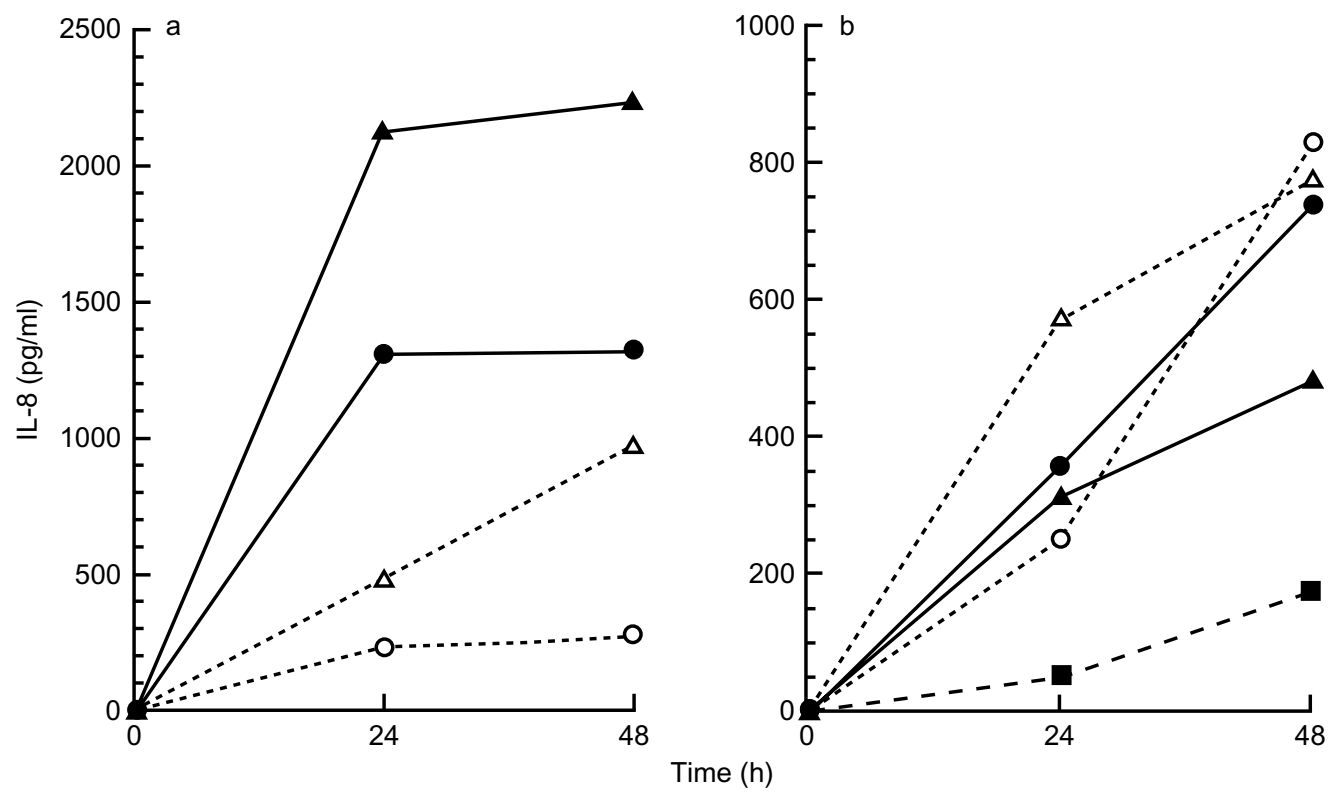

Fig. 2. IL-8 secretion from MKN45 cells following adhesion of helical and coccoid forms of H. pylori. (a) IL-8 secretion by strain

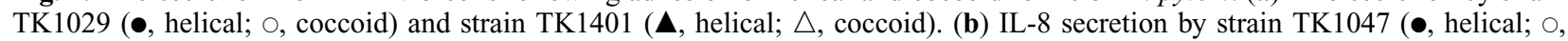
coccoid) and strain TK1045 ( $\mathbf{\Delta}$, helical; $\triangle$, coccoid); $\mathbf{\square}$, control (MKN45 cells).

have been conformationally changed during its binding to the surface of the coccoid form, resulting in less adhesion to gastric epithelial cells.

Cole et al. [12] reported that the coccoid form of $H$. pylori which was obtained by liquid culture under micro-aerobic conditions for $>10$ days, in contrast to the helical form, binds poorly to gastric epithelial cells, AGS and KATO III cells. Less than two coccoid cells were shown to adhere to these gastric epithelial cells by microscopical observation even when $>1 \times 10^{7}$ coccoid cells were added to the gastric cells [12]. However, in the present study, there was no significant difference in the adhesion index between the coccoid and helical forms of two strains (TK1401 and TK1407). Moreover, our electron microscopy study indicated that the coccoid form of H. pylori adhered to MKN45 cells in spite of lower efficacy compared with that of the helical form. Many more of the coccoids form (11.4 SD 10.3 coccoids/MKN45 cell) adhered to MKN45 cells when inoculated with $1 \times 10^{7}$ coccoid cells than the results described by Cole et al. [12].

Vijayakumari et al. [13] reported that specialised attachment sites were seen in the interaction between the coccoid form and gastric epithelial KATO III cells, and that the adhesion patterns of the coccoid form were similar to those observed with helical forms in gastric biopsy specimens. Khin et al. [14] reported that the extracellular matrix and plasma proteins have the ability to bind to both helical and coccoid forms of H. pylori to a similar extent in an ${ }^{125} \mathrm{I}$-labelled protein assay. Furthermore, it was shown that the binding of these proteins to both forms was inibited in the presence of non-labelled protein. In addition to these reports, the results of the present study indicate that the coccoid form can adhere to gastric epithelial cells despite having a lower adhesion index than the helical form.

Morphological conversion from the helical to the coccoid form not only decreases the expression of adhesive substances on the surface but also affects other properties such as motility. As regards the colonisation of the gastric mucosa by $H$. pylori, the helical shape of $H$. pylori and its motility may have some advantages. Eaton et al. [15] reported that a motile flagellate clinical isolate colonised gnotobiotic piglets, whereas a non-motile flagellate variant was able to colonise less effectively. In a preliminary study, microscopic examination showed that the helical form of $H$. pylori moved through liquid media, but the coccoid form did not (data not shown).

Rieder et al. [9] showed that direct contact of bacterial cells with epithelial cells was necessary for optimal IL8 production. The mechanism by which H. pylori induces IL-8 secretion from epithelial cells is unclear. It has been reported that several gene products of the cag pathogenicity island [16], porin [17] and heatshock protein [18] were associated with the induction. Huang et al. [19] reported an IL-8-inducing activity in supernates from overnight culture of $H$. pylori, suggesting that the coccoid form produces less of this kind of activity. Furthermore, the induction of IL-8 secretion was different depending on both the $H$. pylori strains used and the epithelial cells used [20]. In this study, strain diversity in terms of the stimulating activity of IL-8 secretion was demonstrated. The IL-8 induction activity of the coccoid form of strain TK1045 was stronger than that of its helical form. Similarly, the coccoid form of strain TK1047 induced IL-8 secretion 
from MKN45 cells as well as its helical form, although the level $(<1000 \mathrm{pg} / \mathrm{ml})$ of IL-8 induction was not as high as with other strains (TK1029 and TK1401). Strain-dependent IL-8 induction by the coccoid forms was also reported by Cole et al. [12], although the amount of IL-8 induced by the coccoid forms was significantly lower than that induced by the helical forms.

In the present study, there was no correlation between adhesion index and induction of IL-8 secretion from MKN45 cells. This result raises a possibility that factors other than surface adhesin(s) of not only helical but also coccoid forms might be responsible for induction of IL-8. The surface structures of $H$. pylori involved in IL-8 secretion remain to be determined. There have been controversies over the biological significance of the coccoid forms of $H$. pylori. Eaton et al. [20] reported that gnotobiotic piglets could not be infected with coccoidal H. pylori. On the other hand, Cellini et al. [21] showed that colonisation of mouse gastric mucosa by the helical form of $H$. pylori was induced by inoculation of the coccoid form. Wang et al. [22] reported that both spiral and coccoid forms of $H$. pylori can cause acute gastritis and produce an antibody response in BALB/cA mice. The data obtained in the present study suggest that the coccoid form of $H$. pylori may also play some role in colonisation and induction of mucosal inflammation. The mechanisms by which coccoid forms colonise stomach and induce IL-8 secretion remain to be clarified.

\section{References}

1. Benaïssa M, Babin P, Quellard N, Pezennec L, Cenatiempo Y, Fuchère JL. Change in Helicobacter pylori ultrastructure and antigens during conversion from the bacillary to the coccoid form. Infect Immun 1996; 64: 2331-2335.

2. Sörberg M, Nilsson M, Hanberger H, Nilsson LE. Morphologic conversion of Helicobacter pylori from bacillary to coccoid form. Eur J Clin Microbiol Infect Dis 1996; 15: 216-219.

3. Catrenick CE, Makin KM. Characterization of the morphologic conversion of Helicobacter pylori form bacillary to coccoid forms. Scand J Gastroenterol 1991; 26 Suppl. 181: 58-64.

4. Berry V, Jennings K, Woodnutt G. Bactericidal and morphological effects of amoxicillin on Helicobacter pylori. Antimicrob Agents Chemother 1995; 39: 1859-1861.

5. Bode G, Mauch F, Malfertheiner P. The coccoid forms of Helicobacter pylori. Criteria for their viability. Epidemiol
Infect 1993; 111: 483-490.

6. Chan WY, Hui PK, Leung KM, Chow J, Kwok F, Ng CS Coccoid forms of Helicobacter pylori in the human stomach. Am J Clin Pathol 1994; 102: 503-507.

7. Janas B, Czkwianianc E, Bak-Romaniszyn L, Bartel H, Tosik D, Planeta-Malecka I. Electron microscopic study of association between coccoid forms of Helicobacter pylori and gastric epithelial cells. Am J Gastroenterol 1995; 90: 1829-1833.

8. Nilius M, Ströhlel A, Bode G, Malefertheiner P. Coccoid like forms (CLF) of Helicobacter pylori. Enzyme activity and antigenicity. Zentralbl Bakteriol 1993; 280: 259-272.

9. Rieder G, Hatz RA, Moran AP, Walz A, Stolte M, Enders G. Role of adherence in interleukin-8 induction in Helicobacter pylori-associated gastritis. Infect Immun 1997; 65: 3622-3630.

10. Osaki T, Yamaguchi H, Taguchi H, Kumada J, Ogata S, Kamiya S. Studies on the relationship between adhesive activity and haemagglutination by Helicobacter pylori. J Med Microbiol 1997; 46: 117-121.

11. Osaki T, Yamaguchi $\mathrm{H}$, Taguchi $\mathrm{H}$ et al. Establishment and characterisation of a monoclonal antibody to inhibit adhesion of Helicobacter pylori to gastric epithelial cells. J Med Microbiol 1998; 47: 505-512.

12. Cole SP, Cirillo D, Kagnoff MF, Guiney DG, Eckmann L. Coccoid and spiral Helicobacter pylori differ in their abilities to adhere to gastric epithelial cells and induce interleukin-8 secretion. Infect Immun 1997; 65: 843-846.

13. Vijayakumari S, Khin MM, Jiang B, Ho B. The pathogenic role of the coccoid form of Helicobacter pylori. Cytobios 1995; 82: 251-260.

14. Khin MM, Ringnér M, Aleljung P, Wadström T, Ho B. Binding of human plasminogen and lactoferrin by Helicobacter pylori coccoid forms. J Med Microbiol 1996; 45: 433-439.

15. Eaton KA, Moran DR, Krakowka S. Motility as a factor in the colonisation of gnotobiotic piglets by Helicobacter pylori. J Med Microbiol 1992; 37: 123-127.

16. Aihara M, Tsuchimoto D, Takizawa $\mathrm{H}$ et al. Mechanisms involved in Helicobacter pylori-induced interleukin-8 production by a gastric cancer cell line, MKN45. Infect Immun 1997; 65: 3218-3224.

17. Tufano MA, Rossano F, Catalanotti $\mathrm{P}$ et al. Immunobiological activities of Helicobacter pylori porins. Infect Immun 1994, 62: $1392-1399$.

18. Yamaguchi $\mathrm{H}$, Osaki $\mathrm{T}$, Kurihara $\mathrm{N}$ et al. Induction of secretion of interleukin-8 from human gastric epithelial cells by heat-shock protein 60 homologue of Helicobacter pylori. J Med Microbiol 1999; 48: 927-933.

19. Huang J, O'Toole PW, Doig P, Trust TJ. Stimulation of interleukin-8 production in epithelial cell lines by Helicobacter pylori. Infect Immun 1995; 63: 1732-1738.

20. Eaton KA, Catrenick CE, Makin KM, Krakowka S. Virulence of coccoid and bacillary forms of Helicobacter pylori in gnotobiotic piglets. J Infect Dis 1995; 171: 459-462.

21. Cellini L, Allocati N, Angelucci D et al. Coccoid Helicobacter pylori not culturable in vitro reverts in mice. Microbiol Immunol 1994; 38: 843-850.

22. Wang XM, Kojima T, Satoh K et al. The value of LYM-1 cells for examining vacuole formation and loss of cell viability induced by culture supernates of Helicobacter pylori. J Med Microbiol 1997; 46: 705-709. 